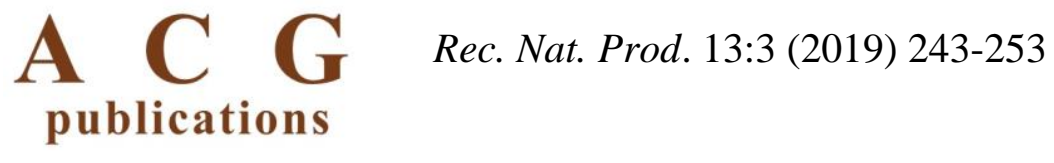

records of natural products

\title{
New Diterpenes Isolated from the Colombian Caribbean Soft Coral Pseudoplexaura flagellosa and their Cytotoxic Properties
}

\author{
Katherine Bauer $\oplus^{1}$, Mónica Puyana $\oplus^{2}$, Leonardo Castellanos $\oplus^{3}$ and \\ Edisson Tello $\oplus^{1 *}$
${ }^{1}$ Faculty of Engineering, Bioprospecting Research Group, Universidad de La Sabana, Chía, Colombia
${ }^{2}$ Department of Biological and Environmental sciences, Universidad Jorge Tadeo Lozano, Bogotá, Colombia.
${ }^{3}$ Chemistry Deparment, Universidad Nacional de Colombia, Bogotá, Colombia

(Received July 12, 2018; Revised October 02, 2018; Accepted October 04, 2018)

\begin{abstract}
Studies about secondary metabolites isolated from soft corals around the world have proven the potential of these organism as producers of compounds with a potent cytotoxic activity. In this work, we obtained the extract of Pseudoplexaura flagellosa collected in Santa Marta, Colombia, the cytotoxic activity of this extract, fractions and compounds was established against SiHa (ATCC® HTB-35TM), MDA-MB-231 (ATCC ${ }^{\circledR}$ HTB26 ${ }^{\mathrm{TM}}$ ), A549 (ATCC® ${ }^{\circledR}$ CRM-CCL-185 ${ }^{\mathrm{TM}}$ ), PC3 (ATCC® CRL1435), and L929 (ATCC® $\mathrm{CCL1}^{\mathrm{TM}}$ ) cell lines. The results showed that the extract of soft coral P. flagellosa has cytotoxic activity with an $\mathrm{IC}_{50}$ of 35.4, 72.3, 49.8 and $40.5 \mu \mathrm{g} / \mathrm{mL}$ against SiHa, A549, PC3 and MDA-MB-231 cell lines, respectively. Thus, this extract was repeatedly subjected to different chromatographic columns and final purification of these fractions afforded pure compounds $1-\mathbf{4}$, which were elucidated by $1 \mathrm{D}$ and $2 \mathrm{D}$ NMR experiments including ${ }^{1} \mathrm{H}$, ${ }^{13} \mathrm{C}, \mathrm{COSY}, \mathrm{HSQC}, \mathrm{HMBC}$ and NOESY, and HRESIMS. In addition, Mosher method was used to establish the stereochemistry of compound $\mathbf{2}$ and chemical interconversion allow establishing the stereochemistry of compound 1. These results let to conclude that compound $\mathbf{2}$ is a new stereoisomers of acetylated asperdiol previously reported on literature. Additionally, three analogues 5, 6, and $\mathbf{7}$ were synthesized from compound $\mathbf{1}$ and the cytotoxic activity of all compounds was evaluated using doxorubicin as positive control. The results showed that 6 ( IC $_{50}$ of 19.3, 23.7, 13.4 and $18.7 \mu \mathrm{g} / \mathrm{mL}$ against $\mathrm{SiHa}, \mathrm{A} 549$, PC3 and MDA-MB-231, respectively) was the most active compound against all the cancer cell lines.
\end{abstract}

Keywords: Pseudoplexaura flagellosa; cytotoxic activity; absolute stereochemistry; stereoisomers; soft corals. (C) 2019 ACG Publications. All rights reserved.

\section{Introduction}

One of the potential sources of compounds with cytotoxic activity are marine invertebrates, among them soft corals (Orders Alcyonacea and Gorgonacea, Class Anthozoa, Phylum Cnidaria [1]). These organisms are prolific sources of compounds, with novel structures conferring them marked biological activity such as anti-inflammatory, antiseptic, acetylcholinesterase inhibition, quorum sensing inhibition and cytotoxicity [2-8].

\footnotetext{
* Corresponding author: E-Mail: edisson.tello@unisabana.edu.co 
Studies on chemistry of soft coral around the world have proven the potential of these organisms as sources of compounds with potent cytotoxic activity. For instance, Lobophytum michaelae (Taiwan), Cladiella sp. (Indonesia), Dichotella gemmacea (China) and Antillogorgia rigida (Bahamas) have yielded compounds with high cytotoxic activity against different cell lines such as P388 (mouse lymphoma), HT-29 (colorectal adenocarcinoma), DLD-1 (colorectal adenocarcinoma), HeLa (cervix carcinoma), MCF-7 (breast adenocarcinoma), A549 (lung carcinoma) and Daoy (medulloblastoma), among others [9-12].

Although Colombia's coral reefs cover an approximate area of $2900 \mathrm{~km}^{2}$, the search of potential applications of products derived from marine invertebrates and microorganisms has not been thoroughly evaluated [13], General calculations indicate that only 70 out of 1914 identified species of marine invertebrates have been chemical characterized or have provided technological applications [14]. Some studies in marine bioprospecting in Colombia have evaluated compounds with biological activity, focusing on medical applications to reduce degenerative processes of the skin [15] and antiinflammatory properties [16,17]. Other studies have evaluated the antifouling potential of organic extracts from marine invertebrates [18] or evaluated mechanisms of quorum sensing inhibition in soft corals $[6,19]$ and, cytotoxic and antiviral activity of compounds isolated from soft corals $[7,8],[20-$ 22].

In our continuous search for novel compounds with promising biological activity from Caribbean marine invertebrates, particularly soft corals, we carried out a statistical study of 42 extracts of octocorals from Colombian Caribbean against a panel of cancer cell lines. From this study, octocoral Pseudoplexaura flagellosa show a selective activity against cervical cancer cell line, for this reason this paper describes the isolation and identification of compounds 1-4 from the organic extract of P. flagellosa and their cytotoxic activity against a panel of human cancer cell lines (SiHa, A549, MDA-MB-231 and PC3), and a mouse fibroblast cell line (L929). Additionally, three synthetic analogues were synthesized to improve the cytotoxic activity of compound $\mathbf{1}$.

\section{Materials and Methods}

\subsection{General Methods}

Optical rotations were measured on a Polartronic ADP440+, Bellinghan \& Stanley polarimeter. NMR spectra were recorded on a Bruker Avance $400\left(400 \mathrm{MHz}\right.$ for ${ }^{1} \mathrm{H}$ and $100 \mathrm{MHz}$ for ${ }^{13} \mathrm{C}$ ) using $\mathrm{CDCl}_{3}$ as solvent unless otherwise stated, with TMS as internal standard. Chemical shifts are given in $\delta$ and coupling constants in Hertz. Mass spectra were determined in a Shimadzu LCMS2010 instrument with a UV/Vis (SPD-10A) detector (detected at $210 \mathrm{~nm}$ ) using a Shimadzu premier C-18 column $(150 \times 4.6 \mathrm{~mm}$ i.d.; $3 \mathrm{~mm})$, with a $\mathrm{A} / \mathrm{B}(70: 30 \% \mathrm{v} / \mathrm{v})$ as eluent where $\mathrm{A}$ was a solution $\mathrm{H}_{2} \mathrm{O} /$ Formic acid at $0.1 \%$ and $\mathrm{B}$ was a solution of ACN/Formic Acid at $0.1 \%$; the flow rate was 0.5 $\mathrm{mL} / \mathrm{min}$. (+)-HRESIMS were obtained using a QSTAR Elite LC/MS (NI 60238).

\subsection{Animal Material}

Branches of the soft coral Pseudoplexaura flagellosa were cut off from a large colony at a depth of $20 \mathrm{~m}$ in Santa Marta Bay, Colombia by scuba diving. The animal material was air dried and then kept frozen until extraction. The animal was identified by the Biologist Ph.D. Mónica Puyana and a voucher was deposited in the Collection of the Institute of Natural Sciences of the National University of Colombia (ICN-MHN-PO 0257).

\subsection{Isolation Procedure}

The animal material (210.3 g) was cut into small pieces and repeatedly extracted with $\mathrm{MeOH}: \mathrm{CH}_{2} \mathrm{Cl}_{2}(1: 1 \mathrm{v} / \mathrm{v})$ and then filtered to yield the corresponding extract $(25.4 \mathrm{~g})$ after rotary evaporation under vacuum. The extract was partitioned between $\mathrm{CH}_{2} \mathrm{Cl}_{2} / \mathrm{H}_{2} \mathrm{O}(1: 1 \mathrm{v} / \mathrm{v})$ to obtain the organic fraction $(11.4 \mathrm{~g})$ that was subjected to flash column chromatography on silica gel $(180 \mathrm{~mm} \times$ 
$50 \mathrm{~mm}$ ) using a gradient of $\mathrm{Hex} / \mathrm{EtOAc} / \mathrm{MeOH}$ (from $100 \%$ n-hexane to $100 \%$ EtOAc and then to $100 \% \mathrm{MeOH}, \mathrm{v} / \mathrm{v})$ to yield 12 fractions (F1-F12) after concentration under vacuum. Crystals were found at the bottom of the vessel that contains fraction F8. This fraction was washed with hexane and recrystallized on EtOAc to obtain pure compound 1 (400 mg). Cytotoxic evaluation of these fractions showed that fractions F3 and F5 were the most active against a panel of cancer cell lines $\left(\mathrm{IC}_{50}\right.$ values lower than $100 \mu \mathrm{g} / \mathrm{mL}$ ) and therefore, these fractions were subjected to further separation.

F5 (1.2 g) was separated by a $\mathrm{SiO}_{2}$ column chromatography $(180 \mathrm{~mm} \times 20 \mathrm{~mm})$ using a gradient of Hex/EtOAc $(9: 1-100 \%$ EtOAc, v/v) providing 92 fractions of $\sim 15 \mathrm{~mL}$. These were grouped in 7 subfractions according to their TLC profile to yield subfractions F5.1-F5.7 after concentration under vacuum. Subfraction F5.5 $(0.070 \mathrm{~g})$ was subjected to silica gel column chromatography $(210 \mathrm{~mm} \times 10 \mathrm{~mm})$ of increasing polarity Hex/EtOAc $(9: 1,8: 2,100 \%$ EtOAc v/v) to afford 92 fractions of $\sim 15 \mathrm{~mL}$ each, that were grouped in 3 subfractions (F5.5.1-F5.5.3) after concentration under vacuum. One of these, subfraction F5.5.2 (40 mg), yielded pure compound 2.

Fraction F3 (4.3 g) was subjected to silica gel column chromatography $(300 \mathrm{~mm} \times 15 \mathrm{~mm})$, eluting with an isocratic gradient of $400 \mathrm{~mL} \mathrm{Hex/EtOAc} \mathrm{9:1,} \mathrm{v/v,} \mathrm{to} \mathrm{yield} 96$ fractions of $\sim 10 \mathrm{~mL}$ each, that were grouped in 14 subfractions (F3.1-F3.14) after concentration under vacuum according to their TLC profile. Subfractions F3.10 and F3.11 contained pure compounds 3 (8.2 mg) and 4 (9.4 $\mathrm{mg}$ ), respectively.

\subsection{Preparation of $R$ - and $S-M P A$ Esters}

To determine the absolute stereochemistry at C-2 of $2,5 \mathrm{mg}$ of 2 were treated with $S$-MPA in $1 \mathrm{~mL}$ of dry DCM with DCC 1.1 equivalent and DMPA in catalytic amounts for $48 \mathrm{~h}$ at room temperature to obtain the $S$-MPA ester at C-2. The reaction mixture was filtered and purified in a silica gel chromatographic column $(10 \mathrm{~mm} \times 50 \mathrm{~mm})$ eluting with a gradient from 9:1 to 8:2 of nhexane/EtOAc to obtain the pure $S$-MPA ester of compound 2 . To obtain the $R$-MPA ester of 2 it follows the same procedure described above, the only difference was the use of $R$-MPA instead $S$ MPA reactant.

Compound 1: colorless crystal; $[\alpha]^{20}{ }_{\mathrm{D}}-40.5\left(\mathrm{c} 1,0 \mathrm{CHCl}_{3}\right)$; IR 3450, 2950, 1650, 1450, $1100 \mathrm{~cm}^{-1}$; the molecular formula was established as $\mathrm{C}_{20} \mathrm{H}_{32} \mathrm{O}_{3}$ by HRESIMS $m / z: 343.2240$ [M+Na] ${ }^{+}$(calculated for $\mathrm{C}_{20} \mathrm{H}_{32} \mathrm{O}_{3} \mathrm{Na}, 343.2249$ ) and the NMR data (Table 1).

Compound 2: yellow crystal; $[\alpha]^{20}{ }_{\mathrm{D}}+57.2\left(\mathrm{c} 2,0 \mathrm{CHCl}_{3}\right)$; IR 3500, 2950, 1720, 1650, 1450, 1050 $\mathrm{cm}^{-1}$; the molecular formula was established as $\mathrm{C}_{22} \mathrm{H}_{34} \mathrm{O}_{4}$ by HRESIMS $\mathrm{m} / z: 385.2345[\mathrm{M}+\mathrm{Na}]^{+}$ (calculated for $\mathrm{C}_{22} \mathrm{H}_{34} \mathrm{O}_{4} \mathrm{Na}, 385.2385$ ) and the NMR data (Table 1).

Compound 3: colorless oil; $[\alpha]^{20}{ }_{\mathrm{D}}+117.7\left(\mathrm{c} 1,0 \mathrm{CHCl}_{3}\right)$; the molecular formula was established as $\mathrm{C}_{20} \mathrm{H}_{34} \mathrm{O}_{3}$ by HRESIMS $m / z: 369.2412[\mathrm{M}+\mathrm{Na}]^{+}$(calculated for $\mathrm{C}_{20} \mathrm{H}_{34} \mathrm{O}_{3} \mathrm{Na}, 369.2406$ ) and the NMR data (Table 1).

Compound 4: colorless oil; $[\alpha]^{20}{ }_{\mathrm{D}}+150.5\left(\mathrm{c} \mathrm{1,2} \mathrm{CHCl}_{3}\right)$; the molecular formula was established as $\mathrm{C}_{20} \mathrm{H}_{30} \mathrm{O}_{2}$ by HRESIMS $m / z: 325.2151[\mathrm{M}+\mathrm{Na}]^{+}$(calculated for $\mathrm{C}_{20} \mathrm{H}_{30} \mathrm{O}_{2} \mathrm{Na}, 325.2143$ ) and the NMR data (Table 1).

\subsection{Preparation of Synthetic Analogues}

\subsubsection{Acetylation of $\mathbf{1}$ and $\mathbf{2}$ with Acetic Anhydride}

The acetylation of $1(0.05 \mathrm{mmol})$ and $2(0.14 \mathrm{mmol})$ were carried out with anhydride acetic (1.5 and $10.4 \mathrm{mmol}$, respectively) in dry DCM and $10 \mu \mathrm{L}$ of $\mathrm{HCl}$ for $48 \mathrm{~h}$ at room temperature. Then, the reaction products were purified in a chromatographic column of $\mathrm{SiO}_{2}$ eluting with a gradient from 95:5 to 84:16 of Hex/EtOAc obtaining the pure compound 5 (quantitative products). 


\subsubsection{Oxidation of 1 with $P C C$}

The oxidation of $1(0.11 \mathrm{mmol})$ was carried out with PCC $(0.17 \mathrm{mmol})$ in dry DCM at room temperature for $3 \mathrm{~h}$. The reaction was quenched with water and then filtered to be purified in a chromatography column eluting with a gradient from 9:1 to 1:1 of Hex/EtOAc to obtain the synthetic analogues $6(0.035 \mathrm{mmol})$ and $7(0.022 \mathrm{mmol})$.

\subsection{Cytotoxicity Assays}

Cell lines MDA-MB-231 human breast epithelial cells (ATCC ${ }^{\circledR}$ HTB26 ${ }^{\mathrm{TM}}$ ) and L929 $\left(\right.$ ATCC ${ }^{\circledR}$ CCL1 $\left.{ }^{\mathrm{TM}}\right)$ were incubated in RPMI medium supplemented with $1 \%(\mathrm{v} / \mathrm{v}) \mathrm{L}$-glutamine, $10 \%$ $(\mathrm{v} / \mathrm{v})$ fetal bovine serum, $1 \%(\mathrm{v} / \mathrm{v})$ penicillin, and $1 \%(\mathrm{v} / \mathrm{v})$ streptomycin. SiHa, human cervix epithelial cells (ATCC® HTB-35 ${ }^{\mathrm{TM}}$ ), human lung cell line A-549 (ATCC® CRM-CCL-185 ${ }^{\mathrm{TM}}$ ) and human prostate epithelial cell lines PC3 (ATCC® CRL1435), were grown in Dulbecco's Modified Eagle's Medium (DMEM) supplemented with antibiotic agents (penicillin $120 \mathrm{IU} / \mathrm{mL}$ and streptomycin $100 \mathrm{IU} / \mathrm{mL}$ ) and $10 \%$ fetal bovine serum.

Cell lines were maintained in a humidified atmosphere of $5 \% \mathrm{CO}_{2}$ at $37{ }^{\circ} \mathrm{C}$. The effect of extracts, fractions and pure compounds was established by MTT assay [23] with modification in the time of exposure of cell lines to fractions or compounds using doxorubicin as positive control. Doxorubicin is often used as a chemotherapeutic for aggressive cancers [24-26]. Cells were grown to approximately $1 \times 10^{5}$ cells/well in 96 well plates and then incubated with various concentrations of extracts, fractions, natural compounds and synthetic analogues, diluted in less than $1 \%$ of DMSO (10, 25, 50, 100 and $200 \mu \mathrm{g} / \mathrm{mL}$ ) at $37{ }^{\circ} \mathrm{C}$ with $5 \% \mathrm{CO}_{2}$ for $48 \mathrm{~h}$. Cell viability was measured with an ELISA microplate reader at wavelength of $570 \mathrm{~nm}$ and $50 \%$ inhibitory concentration $\left(\mathrm{IC}_{50}\right)$ was calculated [27].

\subsection{Statistical Analysis}

Statistical analyses were performed using a Demo License of GraphPad Prism $6^{\circledR}$ and Microsoft ${ }^{\circledR}$ Excel. All the experiments were run by triplicate and the results were expressed as mean values \pm standard deviation. $\mathrm{IC}_{50}$ values were obtained by a nonlinear regression with $\mathrm{R}^{2}>0.95$.

\section{Results and Discussion}

\subsection{Structure Elucidation}

The extract of $P$. flagellosa was partitioned in two phases DCM/ $\mathrm{H}_{2} \mathrm{O} 1: 1$. The organic phase was subjected to silica gel column to afford 12 fractions, which were evaluated along with the organic extract against a panel of cell lines (SiHa, A549, PC3, MDA-MB-231 and L929) using a MTT assay during $48 \mathrm{~h}$. The fractions F3, F5, and F8 were the most active fractions $\left(\mathrm{IC}_{50}\right.$ values $<100 \mu \mathrm{g} / \mathrm{mL}$ against the cancer cell lines), for this reason they were chosen to further separation.

From fraction F8 compound $\mathbf{1}$ was isolated in form of a colorless crystal with molecular formula $\mathrm{C}_{20} \mathrm{H}_{32} \mathrm{O}_{3}$ assigned on the basis of the mass spectrum that exhibited a peak at $\mathrm{m} / z .343 .2240$ $[\mathrm{M}+\mathrm{Na}]^{+}$and the ${ }^{1} \mathrm{H}$ NMR spectrum (Table 1) allowed to establish that compound 1 structure is the known compound asperdiol (Figure 1), first isolated from a soft coral of the genus Eunicea by Weinheimer et al. in 1977 [28]. Both genera, Eunicea and Pseudoplexaura belong to the family Plexauridae. Compound 2 was isolated from subfraction F5.5.2 as a yellow crystal with a molecular formula $\mathrm{C}_{22} \mathrm{H}_{34} \mathrm{O}_{4}$ assigned on the basis of its mass spectrum that presented a peak at $\mathrm{m} / z .385 .2345$ $[\mathrm{M}+\mathrm{Na}]^{+}$and its NMR data (Table 1), corresponding to a diterpene with a cembrane skeleton previously identified as asperdiol acetate (Figure 1), originally isolated from Eunicea knighti [29]. Although both compounds were already reported, this is the first time that they are found in a $P$. flagellosa from the Colombian Caribbean. 
Table 1. NMR data for compounds 1-7 (400 $\mathrm{MHz}$ in $\mathrm{CDCl}_{3}, \delta$ in ppm, $J$ in $\mathrm{Hz}$ )

\begin{tabular}{|c|c|c|c|c|c|c|c|c|c|}
\hline \multirow[b]{2}{*}{ No. } & \multicolumn{2}{|r|}{1} & \multicolumn{2}{|r|}{2} & 3 & \multirow{2}{*}{\begin{tabular}{c}
\multicolumn{1}{c}{4} \\
$\delta \mathrm{H}$, mult, \\
$J(\mathrm{~Hz})$
\end{tabular}} & \multirow{2}{*}{\begin{tabular}{c}
\multicolumn{1}{c}{5} \\
$\delta \mathbf{H}$, mult, \\
$J(\mathbf{H z})$
\end{tabular}} & \multirow{2}{*}{\begin{tabular}{c}
\multicolumn{1}{c}{6} \\
$\boldsymbol{\delta}$ (Hz) mult, \\
\end{tabular}} & \multirow{2}{*}{\begin{tabular}{l}
\multicolumn{1}{c}{7} \\
$\delta H$, mult, \\
$J(\mathbf{H z})$
\end{tabular}} \\
\hline & $\delta \mathrm{C}$ & $\begin{array}{l}\delta \mathrm{H}, \quad \text { mult, } \\
J(\mathrm{~Hz})\end{array}$ & $\delta \mathrm{C}$ & $\begin{array}{l}\delta \mathrm{H}, \text { mult, } \\
J(\mathbf{H z})\end{array}$ & $\begin{array}{l}\delta H, \text { ult, } \\
J(\mathbf{H z})\end{array}$ & & & & \\
\hline 1 & $50.8, \mathrm{~d}$ & $2.05, \mathrm{~m}$ & $50.3, \mathrm{~d}$ & $2.04, \mathrm{~m}$ & $1.96, \mathrm{~m}$ & $2.10, \mathrm{~m}$ & $2.20, \mathrm{~m}$ & $\begin{array}{l}2.55 \\
\mathrm{dd}(9.9,3.0)\end{array}$ & $2.28, \mathrm{~m}$ \\
\hline 2 & $68.5, \mathrm{~d}$ & $\begin{array}{l}4.49, \mathrm{dd} \\
(7.0,6.4)\end{array}$ & $68.3, \mathrm{~d}$ & $4.49, \mathrm{~m}$ & $2.37, \mathrm{~m}$ & $2.12, \mathrm{~m}$ & $\begin{array}{l}5.67 \\
\mathrm{dd}(8.9,3.5)\end{array}$ & - & $\begin{array}{l}4.69, \\
t(7.4)\end{array}$ \\
\hline $2 !$ & & & & & $1.83, \mathrm{~m}$ & $2.71, \mathrm{~m}$ & & & \\
\hline 3 & $128.8, \mathrm{~d}$ & $\begin{array}{l}5.44 \\
d(7.9)\end{array}$ & $\begin{array}{l}132.2, \\
\mathrm{~d}\end{array}$ & $\begin{array}{l}5.47 \\
\mathrm{~d}(7.9)\end{array}$ & $\begin{array}{l}5.54 \\
\mathrm{t}(7.5)\end{array}$ & $\begin{array}{l}6.49 \\
\mathrm{dd}(9.8,5.0)\end{array}$ & $\begin{array}{l}5.40 \\
\mathrm{~d}(8.6)\end{array}$ & 7.01, s & $\begin{array}{l}6.41 \\
\text { d (7.9) }\end{array}$ \\
\hline 4 & 139.7, s & - & $\begin{array}{l}135.4 \\
\mathrm{~s}\end{array}$ & - & - & - & - & - & - \\
\hline 5 & $26.0, \mathrm{t}$ & $2.28, \mathrm{~m}$ & $26.1, \mathrm{t}$ & $2.38, \mathrm{~m}$ & $2.31, \mathrm{~m}$ & $\begin{array}{l}2.34, \\
\mathrm{dt}(10.2, \\
2.5)\end{array}$ & $2.47, \mathrm{~m}$ & $1.77, \mathrm{~m}$ & $1.98, \mathrm{~m}$ \\
\hline $5^{\prime}$ & & & & & $2.24, \mathrm{~m}$ & $2.45, \mathrm{~m}$ & $2.33, \mathrm{~m}$ & $1.62, \mathrm{~m}$ & $1.35, \mathrm{~m}$ \\
\hline 6 & $26.8, \mathrm{t}$ & $1.47, \mathrm{~m}$ & $26.5, \mathrm{t}$ & $1.47, \mathrm{~m}$ & $1.47, \mathrm{~m}$ & $1.47, \mathrm{~m}$ & $1.87, \mathrm{~m}$ & $2.19, \mathrm{~m}$ & $2.26, \mathrm{~m}$ \\
\hline $6^{\prime}$ & & $1.82, \mathrm{~m}$ & & $1.81, \mathrm{~m}$ & $1.88, \mathrm{~m}$ & $1.96, \mathrm{~m}$ & $1.49, \mathrm{~m}$ & $1.98, \mathrm{~m}$ & \\
\hline 7 & $65.0, \mathrm{~d}$ & $\begin{array}{l}2.68, \\
\operatorname{dd}(5.8,4.5)\end{array}$ & $64.0, \mathrm{~d}$ & $\begin{array}{l}2.69 \\
\operatorname{dd}(6.0,4.5)\end{array}$ & $\begin{array}{l}2.73, \\
\mathrm{dd}(7.4, \\
3.4)\end{array}$ & $\begin{array}{l}2.66, \\
\mathrm{dd}(7.1, \\
4.3)\end{array}$ & $2.80, \mathrm{~m}$ & $\begin{array}{l}3.30 \\
\operatorname{dd}(10.1,2.7)\end{array}$ & $2.60, \mathrm{~m}$ \\
\hline 8 & $60.4, \mathrm{~s}$ & - & $60.4, \mathrm{~s}$ & - & - & - & - & - & - \\
\hline 9 & $37.7, \mathrm{t}$ & $1.31, \mathrm{~m}$ & $37.4, \mathrm{t}$ & $1.31, \mathrm{~m}$ & $1.43, \mathrm{~m}$ & $1.46, \mathrm{~m}$ & $1.94, \mathrm{~m}$ & $2.35, \mathrm{~m}$ & $1.91, \mathrm{~m}$ \\
\hline $9^{\prime}$ & & $2.01, \mathrm{~m}$ & & $2.00, \mathrm{~m}$ & $2.00, \mathrm{~m}$ & $1.88, \mathrm{~m}$ & $1.45, \mathrm{~m}$ & $1.72, \mathrm{~m}$ & $1.55, \mathrm{~m}$ \\
\hline $\begin{array}{l}10 \\
10 !\end{array}$ & $24.2, \mathrm{t}$ & $2.18, \mathrm{~m}$ & $24.0, \mathrm{t}$ & $2.18, \mathrm{~m}$ & $\begin{array}{l}2.16, \mathrm{~m} \\
1.62, \mathrm{~m}\end{array}$ & $2.13, \mathrm{~m}$ & $2.20, \mathrm{~m}$ & $\begin{array}{l}1.85, \mathrm{~m} \\
2.01, \mathrm{~m}\end{array}$ & $\begin{array}{l}2.18, \mathrm{~m} \\
2.12, \mathrm{~m}\end{array}$ \\
\hline 11 & $124.8, \mathrm{~d}$ & $\begin{array}{l}5.12 \\
\mathrm{t}(6.9)\end{array}$ & $\begin{array}{l}124.7 \\
\mathrm{~d}\end{array}$ & $\begin{array}{l}5.12 \\
\mathrm{t}(6.6)\end{array}$ & $\begin{array}{l}5.15 \\
\mathrm{t}(6.7)\end{array}$ & $\begin{array}{l}5.22 \\
\mathrm{t}(6.5)\end{array}$ & $5.16, \mathrm{~m}$ & $4.98, \mathrm{~m}$ & $\begin{array}{l}5.14 \\
\mathrm{t}(6.8)\end{array}$ \\
\hline 12 & 135.6, s & - & $\begin{array}{l}135.4 \\
\mathrm{~s}\end{array}$ & - & - & - & - & - & - \\
\hline 13 & $36.3, \mathrm{t}$ & $2.00, \mathrm{~m}$ & $36.0, \mathrm{t}$ & $1.99, \mathrm{~m}$ & $2.14, \mathrm{~m}$ & $2.07, \mathrm{~m}$ & $2.16, \mathrm{~m}$ & $\begin{array}{l}3.38, \mathrm{ddd} \\
(13.0,11.0,3.6)\end{array}$ & $1.83, \mathrm{~m}$ \\
\hline 131 & & & & & $2.20, \mathrm{~m}$ & $2.15, \mathrm{~m}$ & $2.03, \mathrm{~m}$ & & $1.62, \mathrm{~m}$ \\
\hline 14 & $28.2, \mathrm{t}$ & $1.50, \mathrm{~m}$ & $27.9, \mathrm{t}$ & $1.50, \mathrm{~m}$ & $1.44, \mathrm{~m}$ & $1.56, \mathrm{~m}$ & $1.60, \mathrm{~m}$ & $2.16, \mathrm{~m}$ & $2.58, \mathrm{~m}$ \\
\hline $14^{\prime}$ & & $1.74, \mathrm{~m}$ & & & $1.54, \mathrm{~m}$ & $1.65, \mathrm{~m}$ & & $1.67, \mathrm{~m}$ & $2.26, \mathrm{~m}$ \\
\hline 15 & $145.9, \mathrm{~s}$ & - & $\begin{array}{l}145.9, \\
\mathrm{~s}\end{array}$ & - & - & - & - & - & - \\
\hline 16 & $22.5, \mathrm{q}$ & $1.76, \mathrm{~s}$ & $22.4, \mathrm{q}$ & $1.75, \mathrm{~s}$ & $1.65, \mathrm{~s}$ & $1.70, \mathrm{~s}$ & $1.75, \mathrm{~s}$ & $1.64, \mathrm{~s}$ & $1.78, \mathrm{~s}$ \\
\hline 17 & $113.9, \mathrm{t}$ & $4.76, \mathrm{~s}$ & $113.8, \mathrm{t}$ & $4.75, \mathrm{~s}$ & 4.58, br s & 4.66 , br s & 4.85 , br s & $4.89, \mathrm{~s}$ br & $4.79, \mathrm{~s}$ \\
\hline $17 !$ & & $4.95, \mathrm{~s}$ & & $4.95, \mathrm{~s}$ & 4.71, br s & 4.79, br s & 4.64 , br s & $4.82, \mathrm{sbr}$ & $5.01, \mathrm{~s}$ \\
\hline 18 & $65.9, \mathrm{t}$ & $4.06, \mathrm{~m}$ & $67.1, \mathrm{t}$ & $4.49, \mathrm{~m}$ & $\begin{array}{l}4.53 \\
\mathrm{~d}(12.3)\end{array}$ & $9.34, \mathrm{~s}$ & $\begin{array}{l}4.55 \\
\mathrm{~d}(13)\end{array}$ & $9.45, \mathrm{~s}$ & $9.41, \mathrm{~s}$ \\
\hline $18^{\prime}$ & & & & & $\begin{array}{l}4.42, \\
\mathrm{~d}(12.3)\end{array}$ & & $\begin{array}{l}4.45, \\
\mathrm{~d}(13.6)\end{array}$ & & \\
\hline 19 & $16.8, \mathrm{q}$ & $1.19, \mathrm{~s}$ & $16.6, \mathrm{q}$ & $1.19, \mathrm{~s}$ & $1.19, \mathrm{~s}$ & $1.16, \mathrm{~s}$ & $1.25, \mathrm{~s}$ & $1.45, \mathrm{~s}$ & $1.18, \mathrm{~s}$ \\
\hline 20 & $16.0, \mathrm{q}$ & $1.61, \mathrm{~s}$ & $15.8, \mathrm{q}$ & $1.61, \mathrm{~s}$ & $1.58, \mathrm{~s}$ & $1.59, \mathrm{~s}$ & $1.60, \mathrm{~s}$ & $0.91, \mathrm{~s}$ & $1.63, \mathrm{~s}$ \\
\hline 21 & & & $\begin{array}{l}\text { 134.3, } \\
\text { s }\end{array}$ & - & - & & - & & \\
\hline 22 & & & $20.9, \mathrm{q}$ & $2.07, \mathrm{~s}$ & $2.04, \mathrm{~s}$ & & $2.07, \mathrm{~s}$ & & \\
\hline 23 & & & & & & & - & & \\
\hline 24 & & & & & & & $2.05, \mathrm{~s}$ & & \\
\hline
\end{tabular}




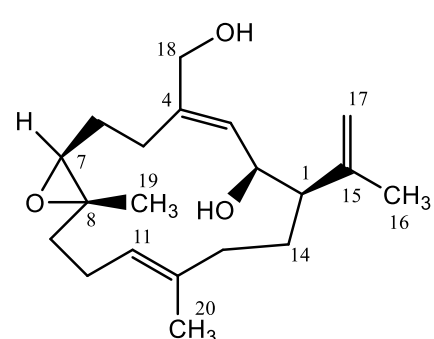

1

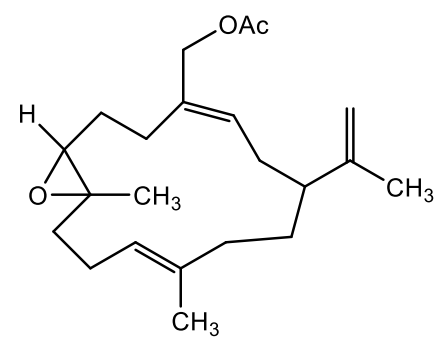

3

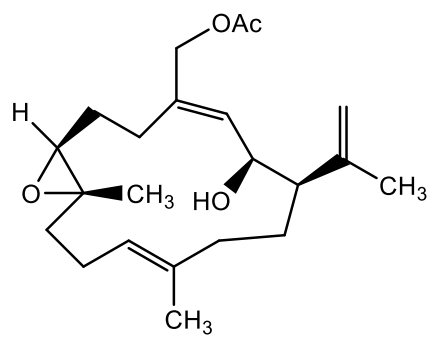

2

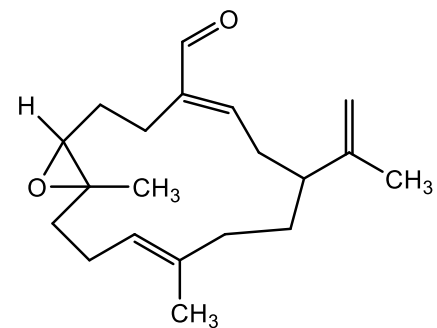

Figure 1. Structure of compounds 1-4

Compound 3 was isolated as a colorless oil with a molecular formula $\mathrm{C}_{22} \mathrm{H}_{34} \mathrm{O}_{3}$ assigned on the basis of HRESIMS spectrum that exhibited a peak at $\mathrm{m} / z 369.2412[\mathrm{M}+\mathrm{Na}]^{+}$and the NMR data (Table 1). The NMR data revealed that 3 is a diterpene with a cembrane skeleton. The ${ }^{1} \mathrm{H}$ NMR spectrum let establish two olefin shifts at $\delta \mathrm{H} 5.15(\mathrm{br} \mathrm{t}, 1 \mathrm{H}, J=6.7 \mathrm{~Hz}), 5.54$ (br t, $1 \mathrm{H}, J=7.9 \mathrm{~Hz}$ ), which have an $E$ configuration based on the steric compression principle; and one more olefin shift at $4.58(\mathrm{~s}, 1 \mathrm{H})$ and $4.71(\mathrm{~s}, 1 \mathrm{H})$ which are two singlets corresponding to the terminal methylene; one signal at $\delta \mathrm{H} 2.73$ (dd, $1 \mathrm{H}, J=7.4,3.4 \mathrm{~Hz}$ ) corresponding to the methine where the epoxide is; two diastereotopic signals at $4.42(\mathrm{~d}, 1 \mathrm{H}, J=12.3 \mathrm{~Hz})$ and $4.53(\mathrm{~d}, 1 \mathrm{H}, J=12.3 \mathrm{~Hz})$ consistent to the methylene bearing the acetate group, and one signal at $\delta \mathrm{H} 2.04(\mathrm{~s}, 1 \mathrm{H})$ corresponding to the methyl of the acetate group. The NMR data and comparing it to the literature allowed us to establish that planar structure of 3 correspond to that of knigthol acetate [29].

Compound $\mathbf{4}$ was isolated from fraction F3.11 as a colorless oil. The HRESIMS of $\mathbf{4}$ exhibited a peak at $\mathrm{m} / \mathrm{z} 325.2151[\mathrm{M}+\mathrm{Na}]^{+}$and the NMR spectroscopic data (Table 1) established a molecular formula of $\mathrm{C}_{20} \mathrm{H}_{30} \mathrm{O}_{2}$ implying the existence of six degrees of unsaturation. The ${ }^{1} \mathrm{H}$ NMR data shown that 4 is structurally similar to 3 , the main difference being the signal at $\delta \mathrm{H} 9.33(\mathrm{~s}, 2 \mathrm{H})$ located in the aldehyde group which replaces the acetate group in 3, receiving the name of knightal isolated for the first time by Tello et al.in 2009[29] from a Eunicea knighti collected in the Colombian Caribbean. These four compounds were previously reported, being compounds $\mathbf{1}, \mathbf{2}, \mathbf{3}$ and 4 the known compounds asperdiol, asperdiol acetate, knightol acetate and knightal, respectively. However, optical rotations for compounds $1(-40.5), 2(+57.2), 3(+117.7)$ and $4(+150.5)$ are opposite to those reported in the literature, suggesting that these compounds are stereoisomers [29].

To establish the stereostructures of the compounds isolated from P. flagellosa, the modified Mosher's method was used to prepare the $R$ - and $S$-MPA esters at C-2 of compound 2 . The chemical shifts difference values (Figure 2) were obtained by comparing the ${ }^{1} \mathrm{H}$ NMR spectrum of $R$ - and $S$ MPA esters (See Supporting Information S13, S14, and S15). Thus, the absolute configuration for C-2 was established as $S$. The configuration of C-1, C-7 and C-8 were established based on NOE correlations observed in the NOESY experiment (Figure 3). The relationship between $\mathrm{H}-2$ with $\mathrm{H}-1$ and $\mathrm{H}-3$ let establish an $R$ configuration in C-1; the cofacial signals of $\mathrm{H}-3$ and $\mathrm{H}-18, \mathrm{H}-18$ and $\mathrm{H}-6$, and the crosspeak between H-6 and H-19, and H-7 and H-9 (see supporting information S8), let establish a trans correlation between H-6 and H-9 confirming a $S$ configuration in C-7 and C-8. All the above, let to establish the absolute stereostructure of compound 2 as (+)-(1R, $2 S, 7 S, 8 S, 3 E, 11 E)-18$ Acetoxycembra-7,8-oxa-3,11,15(17)-trien-2-ol a new stereoisomer of the known asperdiol acetate [29]. To establish the stereostructure of $\mathbf{1}$, compounds $\mathbf{1}$ and $\mathbf{2}$ were acetylated to obtain the 
diacetylated at C-2 and C-18 compound 5 (Table 1). Finally, comparing the ${ }^{1} \mathrm{H}$ NMR data (Table 1) and the optical rotation of both compounds $\mathbf{5}$, it allowed to confirm that the stereochemistry of $\mathbf{1}$ and $\mathbf{2}$ at $\mathrm{C}-1, \mathrm{C}-2, \mathrm{C}-7$, and $\mathrm{C}-8$ are the same, being the compound 1 the $(-)-(1 \mathrm{R}, 2 \mathrm{~S}, 7 \mathrm{~S}, 8 \mathrm{~S}, 3 \mathrm{E}, 11 \mathrm{E})-$ Cembra-7,8-oxa-3,11,15(17)-trien-2,18-diol a stereoisomer of the known asperdiol [28]. The stereochemistry of compound $\mathbf{3}$ and $\mathbf{4}$ could not be stablished due the amount obtained of these compounds, however, tentatively should be the same for compounds $\mathbf{1}$ and $\mathbf{2}$.

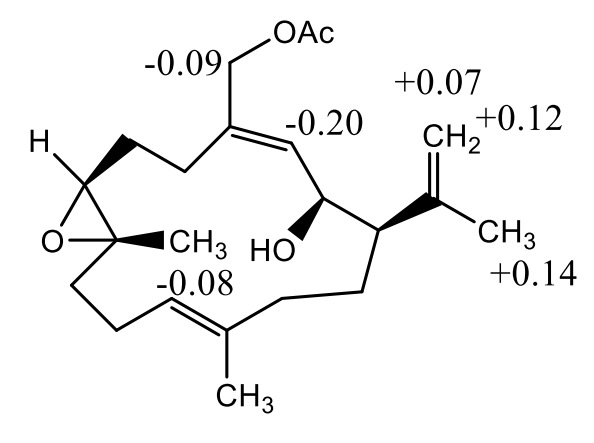

2

Figure 2. Chemical shifts differences between $R$ and $S$-MPA esters of compound $\mathbf{2}$
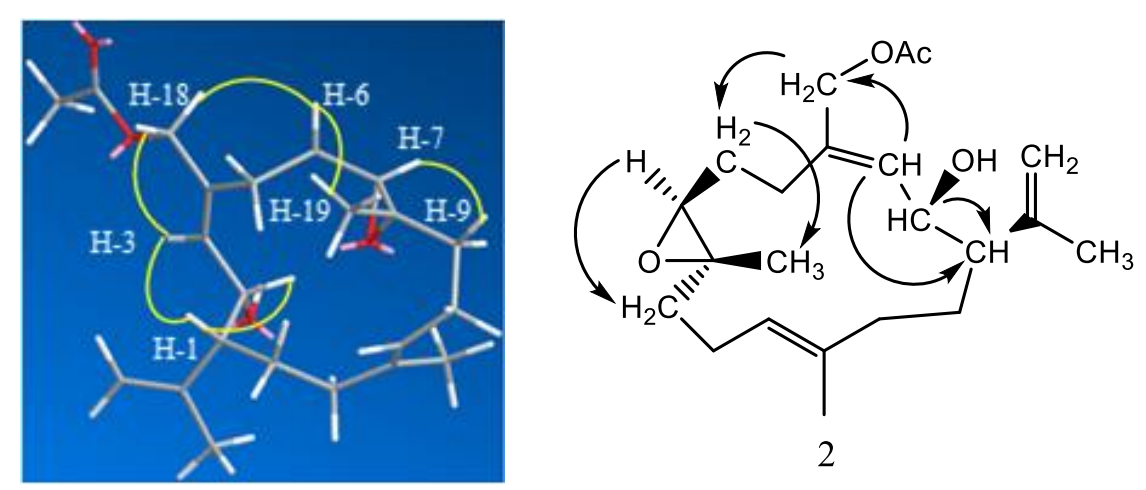

Figure 3. NOESY correlations of compound 2

Additionally, three synthetic analogues were obtained from 1 and were identified through the analysis of ${ }^{1} \mathrm{H}$ NMR spectra. Compound $\mathbf{5}$ was obtained as a product of acetylation of $\mathbf{1}$ and $\mathbf{2}$ (Figure 4), the ${ }^{1} \mathrm{H}$ NMR data showed two different signals at $\delta \mathrm{H} 2.07(\mathrm{~s}, 3 \mathrm{H})$ and $2.05(\mathrm{~s}, 3 \mathrm{H})$ belonging to the methyls of acetyl groups that were expected to be in C-2 and C-18. Compound 6 was obtained by an oxidation of both hydroxyl groups of 1 at C-2 and C-18 (Figure 5). The ${ }^{1} \mathrm{H}$ NMR data (Table 1) let establish the presence of one aldehyde group at C-18 with the signal at $\delta_{\mathrm{H}} 9.45(\mathrm{~s}, 1 \mathrm{H})$, and the absence of any hydrogen signal at $\mathrm{C}-2$ indicated the presence of a ketone group as expected from the reaction. Finally, the mono-keto compound 7 was a subproduct of the same reaction (Figure 5), the ${ }^{1} \mathrm{H}$ NMR data let to establish the presence of one aldehyde signal at $\delta \mathrm{H} 9.41(\mathrm{~s}, 1 \mathrm{H})$ which was assigned to $\mathrm{C}-18$. All the remaining signals were similar to the precursor $\mathbf{1}$. 


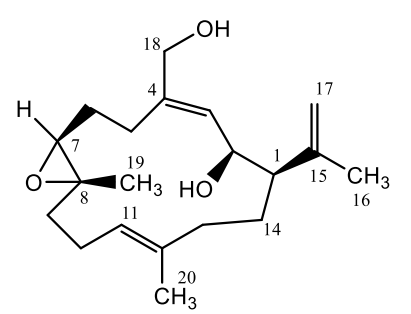

1<smiles>C=C(C)[C@@H](CC/C(C)=C/CC[C@@]1(C)O[C@H]1CC/C(=C\[C@@H](O)COC(C)=O)COC(C)=O)[C@@H]1CO1</smiles>

Acetic Anhydrid DCM. 48 h, RT

Acetic Anhydrid
DCM. 48 h, RT
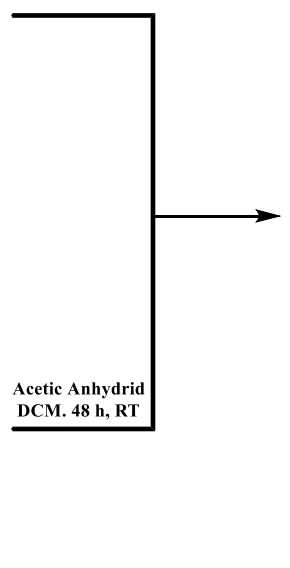<smiles>C=C(C)[C@@H](CC/C(C)=C/CC[C@@]1(C)O[C@H]1CC/C(=C\C(C)C)COC(C)=O)[C@@H](C)OC(C)=O</smiles>

5

Figure 4. Acetylation of $\mathbf{1}$ and $\mathbf{2}$ with acetic anhydride

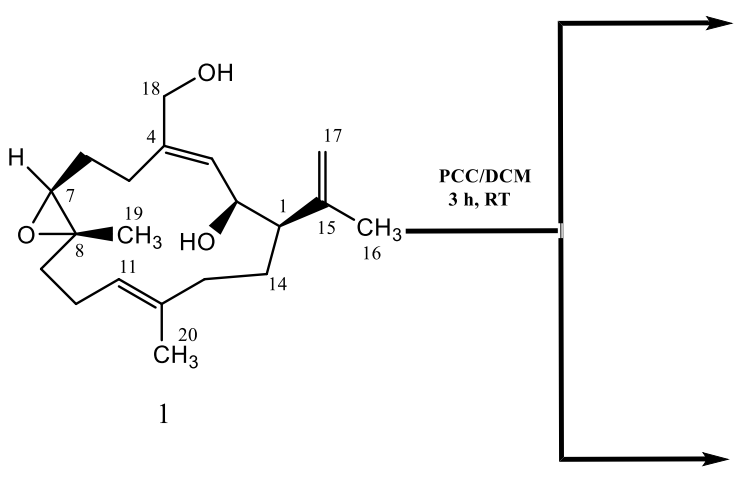<smiles>C=C(C)C(CC/C(C)=C/CC[C@@]1(C)O[C@@H]1CC/C(C=O)=C\C(C)=O)C(=C)C</smiles>

6

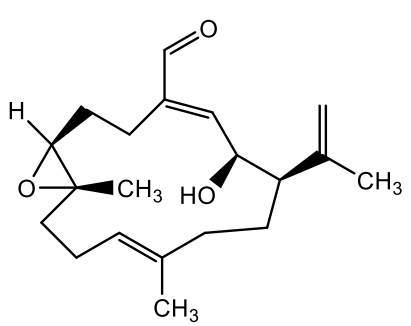

7

Figure 5. Oxidation of 1 with PCC

\subsection{Cytotoxicity Activity}

Cytotoxic assays of the crude extract, fractions and compounds 1-7 was carried out against a panel of four cancer cell lines (PC3, A549, MDA-MB-231, and SiHa), and one fibroblast cell line (L929) (Table 2) using the MTT assay. The extract of $P$. flagellosa showed IC $_{50}$ values between 30-80 $\mu \mathrm{g} / \mathrm{mL}$ against the panel of cell lines mentioned above. Fractions F3, F5 and F8, which contained the isolated compounds, also showed cytotoxic activity between $30-40 \mu \mathrm{g} / \mathrm{mL}$, establishing a correlation activity among the extract and fractions. 
Table 2. Cytotoxicity of compounds 1-7 against a panel of four cancer cell lines

\begin{tabular}{clllll}
\hline \multicolumn{7}{c}{ IC $_{\mathbf{5 0}}(\boldsymbol{\mu g} / \mathbf{m L})$} & & \\
\hline Compound & SiHa & $\mathbf{A 5 4 9}$ & PC3 & MDA-MB-231 & L929 \\
\hline $\mathbf{1}$ & $>100$ & 92.8 & 84.9 & $>100$ & $>100$ \\
$\mathbf{2}$ & 85.6 & 64.0 & 34.2 & $>100$ & $>100$ \\
$\mathbf{3}$ & $>100$ & $>100$ & $>100$ & $>100$ & $>100$ \\
$\mathbf{4}$ & $>100$ & $>100$ & 54.28 & 52.7 & 68.7 \\
$\mathbf{5}$ & 45.7 & 28.9 & 21.1 & 54.2 & $>100$ \\
$\mathbf{6}$ & 19.3 & 23.7 & 13.4 & 18.7 & 55.1 \\
$\mathbf{7}$ & 67.3 & $>100$ & 88.3 & $>100$ & $>100$ \\
Organic Extract & 35.4 & 72.3 & 49.8 & 40.5 & $>100$ \\
Doxorubicin & 5.0 & 0.5 & 1.3 & $>100$ & 0.8 \\
\hline
\end{tabular}

The table 2 show how the functional groups of each compound have a significant role in the cytotoxic activity allowing inferring a structure-activity relationship. It can be observed between compound $\mathbf{1}$ and $\mathbf{2}$ how the presence of the acetate group increases the activity against all the cell lines, but having only the acetate group at C-18 without the hydroxyl group in C-2 decreases significantly the activity against all the cell lines as is shown for compound 3 . Although compound 4 was not active against all the cancer cell lines, the presence of the aldehyde group in C-18 increases the activity compared with compound 3 , who does not have also the hydroxyl group in C-2. Also, the presence of the aldehyde in $\mathbf{4}$ makes the compound the most toxic having cytotoxic activity against the L929 cell line, while the other three compounds did not show activity against this fibroblast cell line. Consequently, this brief structure-activity relationship analysis suggests that the presence of an aldehyde group in C-18 and a hydroxyl group in C-2 will increase the activity against all the cancer cell lines.

Therefore, synthetic analogues that presents this type of combination of functional groups were synthesized to try to increase the activity of its precursors. Thus, compound $\mathbf{5}$ which have two acetyl groups as substituents in $\mathrm{C}-2$ and $\mathrm{C}-18$ was more active than $\mathbf{1}$ and $\mathbf{2}$ (its precursors), confirming that the presence of acetyl groups in this type of molecules increases the cytotoxic activity against the cancer cell lines evaluated in this work. Additionally, compound $\mathbf{6}$ was the most cytotoxic compound showing $\mathrm{IC}_{50}$ values between 10 and $25 \mu \mathrm{g} / \mathrm{mL}$ for all the cell lines, attributing this activity to the aldehyde group located at $\mathrm{C}-18$ and the ketone group at $\mathrm{C}-2$, suggesting that the presence of this type of functional groups in this kind of molecules increases the activity in a wide range. In contrast, compound 7, which have an aldehyde group in C-18 and a hydroxyl group in C-2 did not show an increase of activity.

Although the extract of $P$. flagellosa showed potential activity under $50 \mu \mathrm{g} / \mathrm{mL}$, the compounds isolated from the extract where not as active as the extract, suggesting that the cytotoxic effect of this extract could be a result of a synergistic or additive effect of all active compounds present.

On the other hand, the compound named asperdiol, the diasteroisomer of compound 1, was previously proven to have cytotoxic potential against the leukemia cancer cell line P-388 with an $\mathrm{IC}_{50}$ of $6 \mu \mathrm{g} / \mathrm{mL}$ and HeLa cell line $\mathrm{KB}$ (human cervix carcinoma cell line) with an $\mathrm{IC}_{50} 24 \mu \mathrm{g} / \mathrm{mL}$ [28]. However, the diastereoisomer 1 isolated from $P$. flagellosa did not show significant activity against the $\mathrm{SiHa}$ cell line at $48 \mathrm{~h}$, this could be attributed to the difference in the stereochemical configuration.

It was possible to conclude that the extract of $P$. flagellosa allowed the isolation of four cembranoids, they are stereoisomers of the compounds asperdiol, asperdiol acetate, knightol acetate and knightal, previously reported in literature. Although the organic extract of $P$. flagellosa showed potent activity against the $\mathrm{SiHa}$ cell line, the isolated compounds did not show a significant activity at 48 h. However, compound 4 showed activity against the PC 3 and MDA-MB-231 cell lines, and 2 showed the most promising activity of the natural compounds with the lowest $\mathrm{IC}_{50}$ values for all the four cancer cell lines evaluated. 


\section{Acknowledgments}

We are grateful to the Facultad de Ingeniería and the Dirección de Investigación of Universidad de La Sabana (research project INGPHD-5-2015 "Bioprospección de octocorales del Caribe Colombiano, como una fuente potencial de compuestos con actividad citotóxica" and research project ING-177-2016 "Búsqueda de Compuestos Bioactivos. Fase II: Análogos sintéticos de diterpenos con actividad citotóxica") for financial support. We want to thank Research Group "Estudio y Aprovechamiento de Productos Naturales Marinos y frutas de Colombia" of the Departamento de Química of Universidad Nacional de Colombia for their support in the use of the HPLC and to Servizos de Apoio a Investigación from Universidad de A Coruña (SAI-UDC) for their support in the acquisition of HRESI-MS spectra. Author K.B. acknowledges financial assistance from the MSc Program in Diseño y Gestión de Procesos, Faculty of Engineering.

\section{Supporting Information}

Supporting information accompanies this paper on http://www.acgpubs.org/journal/records-ofnatural-products

\section{ORCID}

Katherine Bauer: 0000-0002-2795-2517

Mónica Puyana: 0000-0001-7600-3118

Leonardo Castellanos: 0000-0001-5248-800X

Edisson Tello: $\underline{0000-0002-6401-8555}$

\section{References}

[1] J.W. Blunt, B.R. Copp, M.H.G. Munro, P.T. Northcote and M.R. Prinsep (2011). Marine natural products, Nat. Prod. Rep. 28 (2), 196-268.

[2] J. Marrero, I.I. Rodrıguez and A.D. Rodríguez (2010). The natural products chemistry of the Gorgonian genus Pseudoptergorgia (Octocorallia: Gorgoniidae), Compr. Nat. Prod. II Chem. Biol. 2, 363-428.

[3] J.-R. Zhang, P.-L. Li, X.-L. Tang, X. Qi and G.-Q. Li (2012). Cytotoxic tetraprenylated alkaloids from the South China Sea gorgonian Euplexaura robusta, Chem. Biodivers. 9 (10), 2218-2224.

[4] Kittakoop, P (2015). Anticancer drugs and potential anticancer leads inspired by natural products, In: Studies in Natural Products Chemistry, ed: Atta-ur-Rahman, Elsevier B.V., Vol. 44, pp 251-307.

[5] S.Y. Cheng, Z.H. Wen, S.K. Wang, S.F. Chiou, C.H. Hsu, C.F. Dai and C.Y. Duh (2009). Antiinflammatory cembranolides from the soft coral Lobophytum durum, Bioorg. Med. Chem. 17 (11), 3763-3769.

[6] E. Tello, L. Castellanos and C. Duque (2013). Synthesis of cembranoid analogues and evaluation of their potential as quorum sensing inhibitors, Bioorg. Med. Chem. 21 (1), 242-256.

[7] C. Duque, M. Puyana, L. Castellanos, A. Arias, H. Correa, O. Osorno, T. Asai, N. Hara and Y. Fujimoto (2006). Further studies on the constituents of the gorgonian octocoral Pseudopterogorgia elisabethae collected in San Andrés and Providencia islands, Colombian Caribbean: isolation of a putative biosynthetic intermediate leading to erogorgiaene, Tetrahedron 62 (17), 4205-4213.

[8] H. Correa, F. Aristizabal, C. Duque and R. Kerr (2011). Cytotoxic and antimicrobial activity of pseudopterosins and seco-pseudopterosins isolated from the octocoral Pseudopterogorgia elisabethae of San Andrés and Providencia islands (southwest Caribbean Sea), Mar. Drugs. 9 (3), 334-344.

[9] S.-K. Wang and C.-Y. Duh (2012). New cytotoxic cembranolides from the soft coral Lobophytum michaelae, Mar. Drugs. 10 (2), 306-318.

[10] Y.-H. Chen, C.-Y. Tai, Y.-H. Kuo, C.-Y. Kao, J.-J. Li, T.-L. Hwang, L.-S. Fang, W.-H. Wang, J.-H. Sheu and P.-J. Sung (2011). Cladieunicellins A-E, new eunicellins from an Indonesian soft coral Cladiella sp, Chem. Pharm. Bull. (Tokyo). 59 (3), 353-358.

[11] P.A. Abreu, D. V. Wilke, A.J. Araujo, J.D.B. Marinho-Filho, E.G. Ferreira, C.M.R. Ribeiro, L.S. Pinheiro, J.W. Amorim, A.L. Valverde, , R.A. Epifanio, L. V. Costa-Lotufo and P.C. Jimenez (2015). Perezone, from the gorgonian Pseudopterogorgia rigida, induces oxidative stress in human leukemia 
cells, Rev. Bras. Farmacogn. 25 (6), 634-640.

[12] C. Li, M.-P. La, P. Sun, T. Kurtan, A. Mandi, H. Tang, B.-S. Liu, Y.-H. Yi, L. Li and W. Zhang(2012). Bioactive (3Z,5E)-11,20-epoxybriara-3,5-dien-7,18-olide diterpenoids from the South China Sea gorgonian Dichotella gemmacea, Mar. Drugs. 9 (8), 1403-1418.

[13] C. Duque, M. Puyana, O. Osorno and S. Zea (2003). Análisis retrospectivo de las investigaciones en productos naturales marinos en Colombia durante los últimos quince años, In: El Mundo Marino de Colombia: investigación y desarrollo de territorios olvidados; Red de Estudios del Mundo MarinoREMAR, ed: Universidad Nacional de Colombia, pp 313-329.

[14] INVEMAR (2014). Informe del Estado de los Ambientes y Recursos Marinos y Costeros en Colombia año 2013.

[15] M.A. Martínez, B.C. Diaz, G.S. Navarro, E.A. Lara, R.J. Colorado and G.L. Atehortua (2012). Activity of sulfated polysaccharides from microalgae Porphyridium cruentum over degenerative mechanisms of the skin, Int. J. Sci. Adv. Technol. 2 (8), 85-92.

[16] E. Reina, F.A. Ramos, L. Castellanos, M. Aragón and L.F. Ospina (2013). Anti-inflammatory Rprostaglandins from Caribbean Colombian soft coral Plexaura homomalla, J. Pharm. Pharmacol. 65, 1643-1652.

[17] H. Correa, A.L. Valenzuela, L.F. Ospina and C. Duque (2009). Anti-inflammatory effects of the gorgonian Pseudopterogorgia elisabethae collected at the Islands of Providencia and San Andrés (SW Caribbean), J. Inflamm. (Lond). 6, 5. doi: 10.1186/1476-9255-6-5.

[18] M.C. Santos-Acevedo, K. Puentes, J. Carreño, M. Gómez León, M. Stupak, M. García, G. Pérez and Blustein. Antifouling paints based on marine natural products from Colombian Caribbean, Int. Biodeterior. Biodegradation 83, 97-104.

[19] C.T. Cuadrado, L. Castellanos, O.E. Osorno, C. Duque and M. Puyana (2010). Estudio químico y evaluación de la actividad antifouling del Octocoral Caribeño Eunicea laciniata, Quim. Nova. 33 (3), 656-661.

[20] C. Duque, M. Puyana, G. Narváez, O. Osorno, N. Hara and Y. Fujimoto (2004). Pseudopterosins P-V, new compounds from the gorgonian octocoral Pseudopterogorgia elisabethae from Providencia island, Colombian Caribbean, Tetrahedron 60 (47), 10627-10635.

[21] J. Quintana, L.M. Bayona, L. Castellanos, M. Puyana, P. Camargo, F. Aristizábal, C. Edwards, J.N. Tabudravu, M. Jaspars and F.A. Ramos (2014). Almiramide D, cytotoxic peptide from the marine cyanobacterium Oscillatoria nigroviridis, Bioorg. Med. Chem. 22 (24), 6789-6795.

[22] A. Pardo-Vargas, F.A. Ramos, C.C. Cirne-Santos, P.R. Stephens, I.C.P. Paixão, V.L. Teixeira and L. Castellanos (2014). Semi-synthesis of oxygenated dolabellane diterpenes with highly in vitro anti-HIV1 activity, Bioorganic Med. Chem. Lett. 24 (18), 4381-4383.

[23] T. Mosmann (1983). Rapid colorimetric assay for cellular growth and survival: application to proliferation and cytotoxicity assays, J. Immunol. Methods. 65 (1-2), 55-63.

[24] C. Nastrucci, A. Cesario and P. Russo (2012). Anticancer Drug Discovery from the Marine Environment, Recent Pat. Anticancer. Drug Discov. 7 (2), 218-232.

[25] G.L. Mariottini and L. Pane (2014). Cytotoxic and cytolytic cnidarian venoms. A review on health implications and possible therapeutic applications, Toxins (Basel). 6 (1), 108-151.

[26] M. Deghrigue, A. Dellai, N. Akremi, V. Le Morvan, J. Robert and A. Bouraoui (2013). Evaluation of antiproliferative and antioxidant activities of the organic extract and its polar fractions from the Mediterranean gorgonian Eunicella singularis, Environ. Toxicol. Pharmacol. 36 (2), 339-346.

[27] J.L. Sebaugh (2011). Guidelines for accurate EC50/IC50 estimation, Pharm. Stat. 10 (2), $128-134$.

[28] A.J. Weinheimer, J.A. Matson, D. van der Helm and M. Poling (1977). Marine anticancer agents: asperdiol, a cembranoid from the gorgonians, Eunicea asperula and E. tourneforti. Tetrahedron Lett. 18 (15), 1295-1298.

[29] E. Tello, L. Castellanos, C. Arevalo-Ferro and C. Duque (2009). Cembranoid diterpenes from the Caribbean sea whip Eunicea knighti, J. Nat. Prod. 72 (9), 1595-1602.

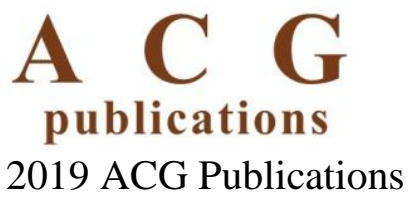

